\title{
SISTEM PENDUKUNG KEPUTUSAN PENENTUAN JURUSAN PADA SMK KERTHA WISATA DENPASAR Menggunakan Fuzzy SAW
}

\author{
I Kadek Dwi Gandika Supartha \\ Dosen Sistem Komputer \\ STMIK STIKOM Indonesia \\ Denpasar-Bali, Indonesia \\ dwigandika[at]gmail.com
}

\author{
I Gusti Ayu Putu Eka Purnama Dewi \\ Mahasiswa Teknik Informatika \\ STMIK STIKOM Indonesia \\ Denpasar-Bali, Indonesia
}

\begin{abstract}
Sistem Pendukung Keputusan (SPK) dapat berupa sebuah sistem berbasis komputer yang menghasilkan berbagai alternatif keputusan untuk membantu manajemen dalam menangani berbagai permasalahan yang terstruktur maupun tidak terstruktur dengan menggunakan data dan model. SPK juga dapat diterapkan untuk menentukan jurusan salah satunya di SMK Kerta Wisata Denpasar.
\end{abstract}

Kriteria yang menjadi inputan ada 6 yaitu: nilai Matematika (C1), nilai Bahasa Indonesia (C2), nilai Bahasa Inggris (C3), nilai IPA (C4), nilai TIK (C5), nilai Keterampilan $(\mathrm{C6})$ dan alternatif yaitu jurusan Akomodasi Perhotelan (AP), Usaha Jasa Pariwisata (UJP), Jasa Boga (JB). Metode yang digunakan yaitu fuzzy dan Simple Additive Weighting (SAW), dengan fuzzy diberikan nilai bobot pada setiap kriteria yang berguna untuk memberikan kejelasan nilai keanggotaan setiap kriteria dan SAW digunakan dalam mencari alternative berdasarkan kriteria yang telah ditentukan. Hasil pengujian menunjukkan bahwa ada data siswa antara minat dan jurusan yang dihasilkan berbeda tentunya hal ini sangat mungkin terjadi karena adanya kriteria nilai, juga bobot masing-masing kriteria.

Keywords-Sistem Pendukung Keputusan (SPK); Fuzzy; Jurusanl; Simple Additive Weighting (SAW)

\section{PENDAHULUAN}

Sekolah Menengah Kejuruan (SMK) Kertha Wisata merupakan salah satu sekolah SMK di Denpasar yang memiliki tiga buah jurusan yaituAP (Akomodasi Perhotelan), UJP (Usaha Jasa Pariwisata) dan JB (Jasa Boga). Sistem pejurusan yang digunakan saat ini masih mengalami kendala karena menggunakan sistem manual, dimana penilaian yang dihasilkan membutuhkan proses yang relatif lama dan belum menghasilkan nilai keputusan yang baik dan tepat untuk siswa, maka diperlukanlah suatu sistem baru penentuan jurusan siswa yang lebih efisien dalam waktu dan tepat dalam memberikan keputusan yang dilihat dari kemampuan dan minat siswa. Kemampuan dan minat siswa didapat dari sistem jalur undangan yang sejenis dengan Penelusuran Minat dan Kemampuan (PMDK), dimana yang akan menjadi pertimbangan dalam penilaian penjurusan yaitu nilai rapor siswa Sekolah Menengah Pertama (SMP) kelas 8 semester 1 dan 2, nilai rapor siswa SMP kelas 9 semester 1. Dari kriteria inilah yang digunakan digunakan dalam proses perhitungan nanti.

Sistem Pendukung Keputusan (SPK) atau Decision Support System (DSS) merupakan suatu sistem berbasis komputer yang dapat membantu seseorang dalam meningkatkan kinerjanya dalam pengambilan keputusan. Dengan menggunakan SPK, diharapkan dapat membantu pengambil keputusan dalam memecahkan masalah yang berada di area semi terstruktur seperti permasalahan diatas.

Dengan adanya permasalahan tersebut, maka dibutuhkan suatu sistem pendukung keputusan dengan menggunakan pembobotan Fuzzy dan metode Simple Additive Weighting (SAW). Pada pembobotan Fuzzy dilakukan proses pemberian nilai bobot pada setiap kriteria yang berguna untuk memberi kejelasan nilai keanggotaan tiap kriteria, sedangkan metode SAW digunakan dalam mencari suatu alternatif terbaik dari berbagai alternatif berdasarkan kriteria-kriteria yang telah ditentukan. Alternatif yang dimaksud adalah siswa dengan nilai terbaik dalam setiap jurusan berdasarkan kriteria yang telah ditentukan. Penelitian dilakukan dengan mencari nilai bobot untuk setiap kriteria dengan fuzzy, kemudian dilakukan proses perangkingan yang akan menentukan alternatif yang terbaik. 


\section{SISTEM PENJURUSAN DI SMK KERTA WISATA}

Sistem penjurusan merupakan proses penyeleksian siswa dalam menentukan jurusan.. Pada saat siswa melakukan registrasi penerimaan siswa baru yang dilaksanakan oleh panitia seleksi, diadakan jalur undangan untuk 50 siswa dimana siswa mengumpulkan hasil raport siswa dari kelas 8 semester 1 dan 2, kelas 9 semester 1. Dan dari nilai tersebutlah didapatkan kriteria untuk dilakukan proses perangkingan berdasarkan kemampuan dan minat terhadap jurusan siswa tersebut.

\section{A. Kriteria Penjurusan}

- Nilai rata-rata Raport

Nilai ini didapat dari penjumlahan nilai kelas 8 semester 1, kelas 8 semester 2 dan kelas 9 semester 1. Dari hasil penjumlahan tersebut dicarilah rata-ratanya kemudian hasil tersebut akan dilakukan pembobotan fuzzy. Adapun nilai rata-rata mata pelajaran yang digunakan sebagai kriteria yaitu : Matematika, Bahasa Indonesia, Bahasa Inggris, IPA, TIK, Keterampilan

- Minat

Minat ini didapat saat siswa mencantumkan minat yang diinginkannya, kemudian nilai ini berupa nilai crisp. Nilai minat ini didapat saat siswa melakukan pendaftaran ke sekolah dengan melakukan interview. Adapun minat yang dimasukkan kedalam kriteria penjurusan yaitu:MinatAP(Akomodasi Perhotelan), Minat UJP (Usaha Jasa Pariwisata), Minat JB (Jasa Boga)

B. Bobot Kriteria Penjurusan

Penentuan penjurusan program studi keahlian Akomodasi Perhotelan, Jasa Boga dan Usaha Jasa Pariwisata dilakukan saat siswa baru sudah melakukan pendaftaran di sekolah. Berikut ini adalah bobot yang diberikan oleh pengambil keputusan disetiap jurusan :

Tabel 1. Pembanding Tiap Jurusan

\begin{tabular}{|l|l|l|l|}
\hline \multirow{2}{*}{\multicolumn{1}{|c}{ Kriteria }} & \multicolumn{3}{c|}{ Jurusan } \\
\cline { 2 - 4 } & AP & UJP & JB \\
\hline Nilai Rata-rata Matematika & B & B & C \\
\hline Nilai Rata-rata Bhs. Indonesia & B & B & B \\
\hline Nilai Rata-rata Bhs. Inggris & C & B & C \\
\hline Nilai Rata-rata IPA & C & C & B \\
\hline Nilai Rata-rata TIK & B & C & K \\
\hline Nilai Rata-rata Keterampilan & C & C & B \\
\hline
\end{tabular}

\section{SISTEM PENDUKUNG KEPUTUSAN(SPK)}

Konsep SPK dapat berupa sebuah sistem berbasis komputer yang menghasilkan berbagai alternatif keputusan untuk membantu manajemen dalam menangani berbagai permasalahan yang terstruktur maupun tidak terstruktur dengan menggunakan data dan model [5]. SPK dirancang agar mampu untuk menunjang seluruh tahapan pembuatan keputusan, seperti tahap pengindetifikasian masalah, pemilihan data, penentuan pendekatan hingga untuk mengevaluasi pemilihan alternatif [4].

SPK dapat didefinisikan sebagai model dari sekumpulan prosedur yang digunakan untuk melakukan pengolahan data dengan tujuan agar dapat membantu manajer dalam pembuatan keputusan yang sifatnya spesifik [5]. Penerapan SPK hanya akan berhasil jika sistem bersifat sederhana, mudah untuk digunakan, mudah dalam melakukan pengawasan, mudah beradaptasi dengan perubahan lingkungan serta mudah berkomunikasi dengan jenis entity yang lain.

SPK dapat diterapkan pada situasi dimana sistem akhir hanya dapat dikembangkan melalui proses pembelajaran, serta evolusi yang adaptif. SPK merupakan hasil dari proses pengembangan dimana pengguna dan pembangun SPK merupakan hasil dari proses pengembangan dimana pengguna dan pembangun SPK serta SPK tersebut harus mampu untuk saling mempengaruhi satu dengan yang lainnya kemudian menghasilkan evolusi sistem dengan pola-pola penggunaan [4].

\section{HIMPUNAN FUZZY}

Pada dasarnya, teori himpunan fuzzy merupakan perluasan dari teori himpunan klasik. Pada teori himpunan klasik (crisp), keberadaan suatu elemen pada suatu himpunan, A, hanya akan memiliki 2 kemungkinan keanggotaan, yaitu menjadi anggota $\mathrm{A}$ atau tidak menjadi anggota $\mathrm{A}$ [1]. Suatu nilai yang menunjukkan seberapa besar tingkat keanggotaan suatu elemen $(\mathrm{x})$ dalam suatu himpunan (A), sering dikenal dengan nilai keanggotaan atau derajat keanggotaan, dinotasikan dengan $\mu \_A(x)$. Pada himpunan klasik, hanya ada 2 nilai keanggotaan, yaitu $\mu$ A $(x)=1$ untuk $x$ menjadi anggota $\mathrm{A}$; dan $\mu \mathrm{A}(\mathrm{x})=0$ untuk $\mathrm{x}$ bukan anggota dari $\mathrm{A}$.

Fungsi keanggotaan (membership function) adalah suatu kurva yang menunjukkan pemetaan titik-titik input data kedalam nilai keanggotaanya yang memiliki interval antara 0 sampai 1. Salah satu cara yang dapat digunakan untuk mendapatkan nilai keanggotaan adalah dengan 
melalui pendekatan fungsi [2]. Ada beberapa fungsi yang digunakan pada penelitian ini, sebagai berikut:

\section{- Representasi Linear}

Ada 2 keadaan himpunan fuzzy yang linear. Pertama, kenaikan himpunan dimulai pada nilai domain yang memiliki derajat keanggotaan nol (0) bergerak ke kanan menuju ke nilai domain yang memiliki derajat keanggotaan lebih tinggi.

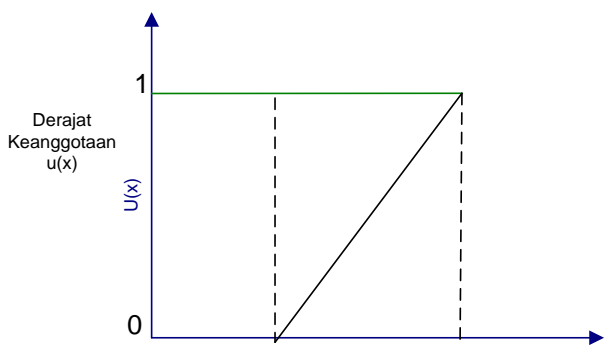

Sumber : [3]

Gambar 1 Representasi Linear Naik

Fungsi Keanggotaan :

$\mu_{[x]}=\left\{\begin{array}{lr}0, & x \leq a \\ \frac{x-a}{b-a}, & a \leq x \leq b . \\ 1_{x} & x \geq b\end{array}\right.$.

Kedua, merupakan kebalikan yang pertama. Garis lurus dimulai dari nilai dominan dengan derajat keanggotaan tertinggi pada sisi kiri, kemudian bergerak menurun ke nilai domain yang memiliki derajat keanggotaan lebih rendah.

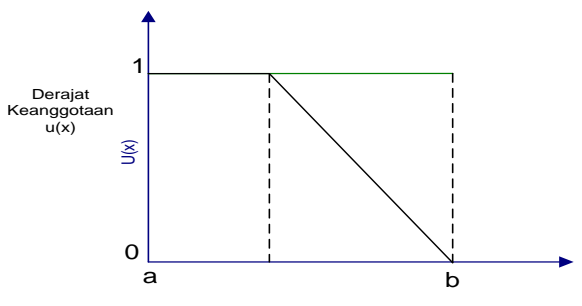

Sumber : [3]

Gambar 2 Representasi Linear Turun

Fungsi Keanggotaan :

$\mu_{[x]}=\left\{\begin{array}{lr}1_{x} & x \leq b \\ \frac{b-x}{b-a}{ }^{2} & a \leq x \leq b \\ 0, & x \geq b\end{array}\right.$

- Representasi Kurva Segitiga

Kurva segitiga pada dasarnya merupakan gabungan antar 2 garis (linear) seperti terlihat pada gambar dibawah ini :

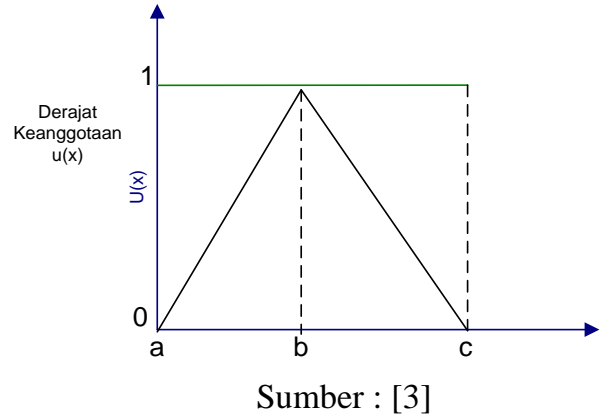

Gambar 3 Representasi Kurva Segitiga

Fungsi Keanggotaan :

$\mu_{[x]}=\left\{\begin{array}{lr}0, & x \leq a \text { atau } x \geq c \\ \frac{x-a}{b-a^{0}} & a \leq x \leq b \\ \frac{b-x}{c-b}{ }^{v} & b \leq x \leq c\end{array} \ldots \ldots\right.$.

(3)

- Representasi Kurva Trapesium

Kurva segitiga dasarnya bentuk segitiga, hanya saja ada beberapa titik yang memiliki nilai keanggotaan 1 .

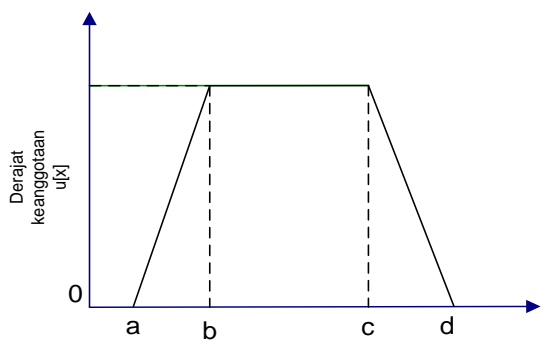

Sumber : [4]

Gambar 4 Representasi Kurva Trapesium

Fungsi Keanggotaan :

$$
\mu_{[X]}=\left\{\begin{array}{lc}
0, & x \leq a \text { atau } x \geq d \\
\frac{x-a}{b-a}, & a \leq x \leq b \\
1_{x} & b \leq x \leq c \cdots \cdots \ldots . \\
\frac{d-x}{d-c}, & x \geq d
\end{array}\right.
$$

\section{V.SIMPLE ADDITIVE WEIGHTING (SAW)}

Metode SAW sering juga dikenal istilah metode penjumlahan terbobot. Konsep dasar metode SAW adalah mencari penjumlahan terbobot dari rating kinerja pada setiap alternatif pada semua atribut. Metode SAW membutuhkan proses normalisasi matriks keputusan (X) ke suatu skala yang dapat diperbandingkan dengan semua rating alternative yang ada [2]. 
$r_{i j}= \begin{cases}\frac{X_{i j}}{\operatorname{Max} X_{i j}} & \text { Jika } j \text { adalah atribut keuntungan } \\ \frac{\operatorname{Min} X_{i j}}{X_{i j}} & \text { Jikaj adalahatribut biaya(cost) }\end{cases}$

Keterangan :

$r_{\mathrm{i} j}=$ nilai rating kinerja ternormalisasi

$x_{i j} \quad=$ nilai atribut yang dimiliki dari setiap

kriteria

$\operatorname{Max}_{i \mathrm{ij}} \quad=$ nilai terbesar dari setiap kriteria

$\operatorname{Min}_{\mathrm{i}} x_{i j} \quad=$ nilai terkecil dari setiap kriteria

benefit = jika nilai terbesar adalah terbaik

cost $=$ jika nilai terkecil adalah terbaik

dimana $r_{i j}$ adalah rating kinerja ternormalisasi dari alternatif $A_{\mathfrak{i}}$ pada atribut $C_{\vec{j}} ; \quad \mathrm{i}=1,2, \ldots, \mathrm{m}$ dan $\mathrm{j}=1,2, \ldots, n$. Nilai preferensi untuk setiap alternatif $\left(V_{i}\right)$ diberikan sebagai:

$V_{i}=\sum_{j=1}^{n} W_{j} r_{i j}$

Keterangan :

$V_{i} \quad$ = rangking untuk setiap alternatif

$w_{j}=$ nilai bobot dari setiap kriteria

$r_{\mathrm{i} j} \quad=$ nilai rating kinerja ternormalisasi

\section{RANCANGAN APLIKASI}

A. Kriteria dan Bobot

Berikut ini merupakan kriteria yang dibutuhkan dalam mengambil keputusan menentukan jurusan. Kriteria yang telah ditentukan sebagai berikut :

1. Nilai rata-rata Matematika $(\mathrm{C} 1)$

2. Nilai rata-rata Bahasa Indonesia (C2)

3. Nilai rata-rata Bahasa Inggris $(\mathrm{C} 3)$

4. Nilai rata-rata IPA (C4)

5. Nilai rata-rata TIK (C5)

6. Nilai rata-rata Keterampilan (C6)

7. Minat AP (C7)

8. Minat UJP (C8)

9. Minat JB (C9)

Dari kriteria tersebut, maka dibuat suatu tingkat kepentingan kriteria berdasarkan nilai terbobot yang telah ditentukan kedalam bilangan fuzzy. Rating kecocokan setiap alternatif (penilaian) pada setiap kriteria yaitu Kurang (K), Cukup (C), dan Baik (B), seperti yang terlihat pada Gambar 5 dibawah ini:

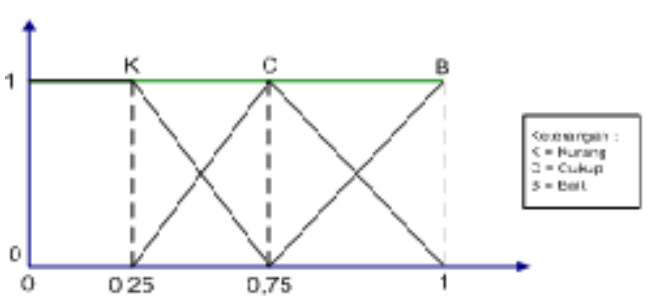

Gambar 5 Grafik Nilai Preferensi Tiap Kriteria

Dari gambar 5, pengambil keputusan memberikan nilai kepentingan pada setiap kriteria, kemudian dikonversikan kedalam bilangan crisp. Untuk lebih jelas data bobot dibentuk dalam tabel dibawah ini :

Tabel 2 Nilai Preferensi Tiap Kriteria

\begin{tabular}{|l|l|l|l|}
\hline \multirow{2}{*}{\multicolumn{1}{|c|}{ Kriteria }} & \multicolumn{3}{c|}{ Jurusan } \\
\cline { 2 - 4 } & AP & UJP & JB \\
\hline Nilai Rata-rata Matematika & B & B & C \\
\hline Nilai Rata-rata Bhs. Indonesia & B & B & B \\
\hline Nilai Rata-rata Bhs. Inggris & C & B & C \\
\hline Nilai Rata-rata IPA & C & C & B \\
\hline Nilai Rata-rata TIK & B & C & K \\
\hline Nilai Rata-rata Keterampilan & C & C & B \\
\hline Minat AP & B & K & K \\
\hline Minat UJP & K & B & K \\
\hline Minat JB & K & K & B \\
\hline
\end{tabular}

Maka didapatkan nilai crisp pada setiap alternatif sebagai berikut :

Tabel 3 Nilai Preferensi Bobot Tiap Kriteria

\begin{tabular}{|l|l|l|l|}
\hline \multirow{2}{*}{ Kriteria } & \multicolumn{3}{|l|}{ Jurusan } \\
\cline { 2 - 4 } & AP & UJP & JB \\
\hline C1 & 1 & 1 & 0,75 \\
\hline C2 & 1 & 1 & 1 \\
\hline C3 & 0,75 & 1 & 0,75 \\
\hline C4 & 0,75 & 0,75 & 1 \\
\hline C5 & 1 & 0,75 & 0,25 \\
\hline C6 & 0,75 & 0,75 & 1 \\
\hline C7 & 1 & 0,25 & 0,25 \\
\hline C8 & 0,25 & 1 & 0,25 \\
\hline C9 & 0,25 & 0,25 & 1 \\
\hline
\end{tabular}

\section{B. Gambaran Umum Sistem}

Gambaran umum sistem sistem pendukung keputusan penentuan jurusan dapat dilihat pada Gambar 6 dibawah ini:

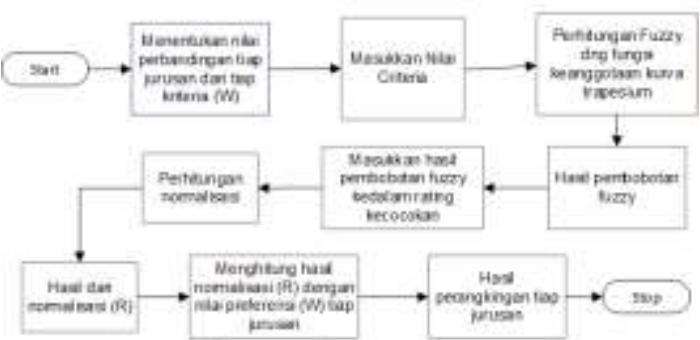




\section{Gambar 6. Gambaran Umum Sistem \\ VII. IMPLEMENTASI DAN HASIL PENGUJIAN}

Hasil implementasi dari rancangan aplikasi akan membentuk interface untuk perhitungan seperti pada Gambar 7

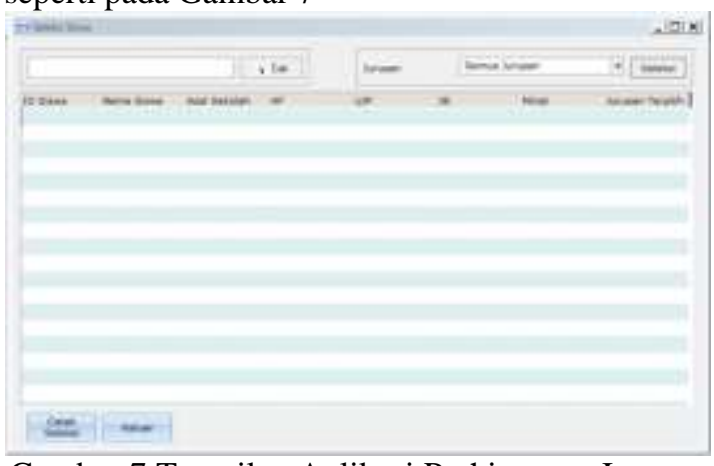

Gambar 7 Tampilan Aplikasi Perhitungan Jurusan

Gambar 7 merupakan form aplikasi yang digunakan untuk melakukan perhitungan berdasarkan kriteria nilai dari beberapa calon siswa. Proses pengujian akan menggunakan data 5 orang siswa dengan nilai kriteria yang telah dirataratakan ditunjukkan pada Tabel 4 :

Tabel 4 Data Pengujian

\begin{tabular}{|c|c|c|c|c|c|c|c|c|}
\hline No & Siswa & MrTK & INDO & ING & IPA & IIK & KTR & MINAT \\
\hline & 51 & 65.67 & 72.33 & 74.33 & 7233 & 7667 & 73.33 & AP \\
\hline 25 & $\$ 2$ & 74,00 & 73.00 & $\theta 8.00$ & 70.00 & 71.67 & 76.00 & IB \\
\hline 3 s & $\$ 3$ & 81.67 & 68.00 & 81. 33 & 75.33 & 78.33 & 78.33 & $\mathrm{AP}^{\mathrm{P}}$ \\
\hline 45 & \$1 & 2.33 & 80.00 & 81.60 & 61.00 & 62.33 & 62.33 & UIP \\
\hline $5:$ & S5 & 70.67 & 82.33 & 62.33 & 80.67 & 65.00 & 6200 & $A P$ \\
\hline 6 & 86 & 74.33 & Q. 33 & 65.33 & 70.67 & 8000 & 8033 & I \\
\hline 75 & 57 & 79.33 & 71.67 & 72.67 & 79.33 & 8000 & 78.33 & UPP \\
\hline 8 & S8. & 64.00 & 65.00 & 88.67 & 39.00 & 82.33 & 8400 & AP \\
\hline 9 & 99 & 80.67 & 71.33 & 81.33 & 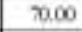 & 73,33 & 80.67 & UIP \\
\hline 10 & $\mathbf{\$} 10$ & $74.6 ?$ & 83.33 & 81.00 & 65,00 & 62.33 & 6600 & AP \\
\hline 11 & 811 & 68.33 & $\$ 2.67$ & 66.67 & 62.33 & 75,00 & 76.67 & $A^{P}$ \\
\hline 12 s & $\$ 12$ & 71.33 & 81.67 & 65.00 & 50.67 & 81.67 & 67.67 & IB \\
\hline 13 & 813 & 80.67 & 66.33 & 78.00 & 60.33 & 73.00 & 7000 & B \\
\hline 145 & $\$ 14$ & 2.33 & 68.00 & 76.00 & 71.00 & 81.00 & 80.67 & UJP \\
\hline 15 & 515 & 82.67 & 81.00 & 69.00 & 66.67 & 69.67 & 7200 & AP \\
\hline
\end{tabular}

Keterangan :

Kriteria

MTK : Nilai matematika

IND : Nilai Bahasa Indonesia

ING : Nilai Bahasa Inggris

IPA : Nilai IPA

TIK : Nilai TIK

KTR : Nilai Keterampilan
Data pengujian tersebut diinputkan kedalam aplikasi dan berikut ini merupakan output dari perhitungan sistem :

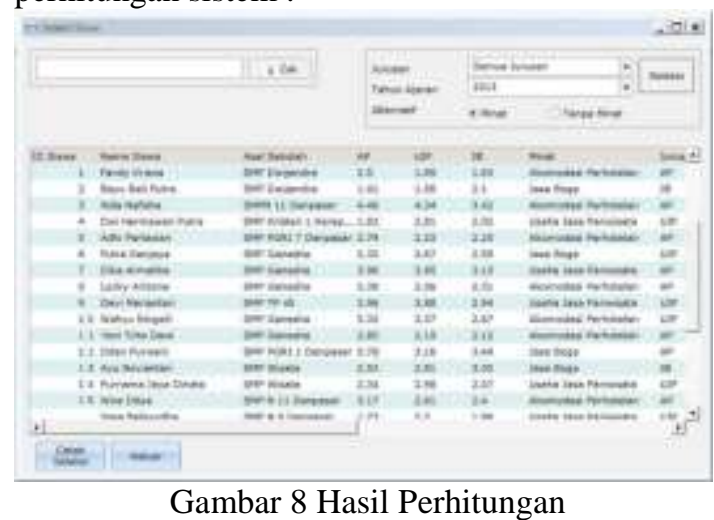

\section{ANALISIS HASIL PENGUJIAN}

Hasil pengujian memberikan gambaran tentang performa kerja dari aplikasi yang dibuat. Berdasarkan pengujian yang talah dilakukan sebelumnya terhadap 5 data siswa yang ditunjukkan pada Gambar 8 atau jika disajikan dalam bentuk tabel dapat dilihat seperti tabel 5 berikut:

Tabel 5. Hasil Pengujian

\begin{tabular}{|r|l|c|c|c|c|c|}
\hline No & Siswa & AP & UJP & JB & Minat & Jurusan \\
\hline 1 & $\mathrm{~S} 1$ & 2,5 & 1,89 & 1,63 & AP & AP \\
\hline 2 & $\mathrm{~S} 2$ & 1,41 & 1,56 & 2,1 & JB & JB \\
\hline 3 & $\mathrm{~S} 3$ & 4,46 & 4,34 & 3,42 & AP & AP \\
\hline 4 & $\mathrm{~S} 4$ & 1,83 & 2,81 & 2,02 & UJP & UJP \\
\hline 5 & $\mathrm{~S} 5$ & 2,79 & 2,23 & 2,25 & AP & AP \\
\hline 6 & $\mathrm{~S} 6$ & 2,32 & 2,67 & 2,59 & JB & UJP \\
\hline 7 & $\mathrm{~S} 6$ & 3,96 & 3,95 & 3,13 & UJP & AP \\
\hline 8 & $\mathrm{~S} 8$ & 3,38 & 2,56 & 2,31 & AP & AP \\
\hline 9 & $\mathrm{~S} 9$ & 2,96 & 3,88 & 2,94 & UJP & UJP \\
\hline 10 & $\mathrm{~S} 10$ & 3,33 & 3,37 & 2,67 & AP & UJP \\
\hline 11 & $\mathrm{~S} 11$ & 2,85 & 2,19 & 2,12 & AP & AP \\
\hline 12 & $\mathrm{~S} 12$ & 3,78 & 3,16 & 3,44 & JB & AP \\
\hline 13 & $\mathrm{~S} 13$ & 2,52 & 2,81 & 3,05 & JB & JB \\
\hline 14 & $\mathrm{~S} 14$ & 2,34 & 2,98 & 2,07 & UJP & UJP \\
\hline 15 & $\mathrm{~S} 15$ & 3,17 & 2,61 & 2,4 & AP & AP \\
\hline
\end{tabular}

Dari tabel di atas dapat dilihat dari 5 data calon siswa, 4 data siswa yaitu S1, S2, S3, S5 antara minat dan jurusan terpilih sama yang artinya calon siswa tersebut memperoleh jurusan sesuai dengan minatnya, sedangkan calon siswa S4 antara minat dan jurusan yang terpilih berbeda dimana minat 
siswa tersebut yaitu JB ternyata jurusan yang terpilih yaitu UJP. Hal tersebut sangat mungkin terjadi karena dari semua kriteria yang ikut dalam perhitungan sangat menentukan hasil dari jurusan yang terpilih.

\section{PENUTUP}

Setelah melalui serangkaian perancangan dan percobaan maka didapatkan beberapa point penting sebagai rangkuman kegiatan penelitian iniataupun saran pengembangan untuk penelitian lanjutan, yaitu.

1. Aplikasi yang dibangun telah mampu menghasilkan penjurusan berdasarkan kriteria dan bobot yang telah diinputkan sebelumnya ke dalam sistem dalam waktu yang relatif singkat sehingga akan sangat membantu mempercepat penentuan jurusan siswa baru yang sebelumnya dilakukan dnegan proses manual.

2. Jurusan yang dihasilkan oleh sistem dipengaruhi oleh nilai kriteria dan bobot yang diinputkan yaitu 6 kriteria yang di fuzzykan (C1, C2, C3, C4, C5, C6) dan 3 kriteria yang bersifat crips (C7, C8, C9) sehingga memungkinkan antara minat siswa dan hasil dari sistema menghasilkan jurusan yang berbeda.

\section{REFERENSI}

[1] Chak, C.K., Feng, G., dan Palasniswani, M., 1998. Implementation of Fuzzy Systems. Dalam Leondes, Cornelius T.1998. Fuzzy Logic and Expert Systems Applications. Volume 6 Neural Network Systems Techniques and Applications. London : Academic Press.Fausett, Laurene. 1994. "Fundamentals Of Neural Networks". Prentice-Hall

[2] Kusumadewi,S., Hartati,S., Harjoko,S., dan Wardoyo,R., 2006. "Fuzzy Multi-Attribute Decision Making (Fuzzy MADM)". Yogyakarta : Penerbit Graha Ilmu.

[3] Kusumadewi, S. dan Purnomo, H., 2010. "Aplikasi Logika Fuzzy untuk Pendukung Keputusan". Edisi 2. Yogyakarta : Penerbit Graha Ilmu.

[4] Setyono, P.H.. 2007. "Sistem Pendukung Keputusan Untuk Menilai Kualitas Layanan Dengan Metode AHP dan Promethee". Skripsi Ilmu Komputer. FMIPA. Universitas Gadjah Mada, Yogyakarta.

[5] Turban, E; J.E.Aronson; dan T.Liang. 2005, Decision Support System and Intelegent System, Pearson Prantince Hall, New Jersey. 